\title{
Kompetensi Pendidik Dan Tenaga Kependidikan Pada Pendidikan Nonformal
}

\author{
Siswantari \\ Pusat Penelitian Kebijakan, Balitbang Kemdiknas \\ Email: siswantariarin@gmail.com
}

\begin{abstract}
Abstrak: Pendidik dan tenaga kependidikan (PTK) memegang peran yang begitu penting dalam upaya meningkatkan mutu pendidikan, termasuk pada pendidikan non-formal. Untuk itu Pemerintah selalu berupaya untuk meningkatkan kompetensi mereka. Namun demikian, kompetensi mereka belum banyak diketahui. Dengan mengetahui kompetensi mereka, perancangan pelatihan dapat dilakukan dengan lebih efisien dan efektif. Lingkup penelitian ini meliputi program Paket A dan Paket B. Pendidik adalah tutor program Paket A dan Paket B yang tidak merangkap sebagai guru di sekolah dan pamong belajar kelompok kerja (pokja) pendidikan kesetaraan di P2PNFI dan BPPNFI, BPKB, dan SKB. Tenaga Kependidikan meliputi pengelola kelompok belajar Paket A dan Paket B serta Penilik. Pengumpulan data dilakukan dengan memberi tes kepada responden dan wawancara dengan beberapa responden. Hasil tes memperlihatkan bahwa kompetensi mereka secara umum masih rendah. Dengan demikian diperlukan upaya Pemerintah dan pemerintah daerah untuk meningkatkan kompetensi mereka dalam rangka meningkatkan mutu pendidikan non-formal.
\end{abstract}

Kata kunci: Pendidikan non-formal, tutor, pamong belajar, pengelola kelompok belajar, Penilik.

\begin{abstract}
Teacher and education personnel have important roles to improve the quality of education, including non-formal education. Government always improves their competence. However, so far not many people know about their competence. By knowing their competence, then training can be designed more efficiently and more effectively. The scope of the study are Package A and Package B programs. Educator is a tutor for program Package A and Package B which at the same time is not a teacher in schools. Including educator is pamong belajar who handle kesetaraan education in P2PNFI and BPPNFI, BPKB, and SKB. Education personnel include study group manager of Package A and/or Package B and inspectors (Penilik). The data was collected by testing the respondents and interviews with some respondents. The test results showed that their competence is generally still low. Thus the necessary effort of the Government and local governments is to improve their competence in order to improve the quality of non-formal education.
\end{abstract}

Key words: non-formal education, tutor, pamong belajar, study group manager, penilik.

\section{Pendahuluan}

Menurut Undang-Undang Nomor 20 tahun 2003 tentang Sistem Pendidikan Nasional (UUSPN) pasal 26, pendidikan non formal (PNF) adalah pengganti, penambah, dan/atau pelengkap pendidikan formal dalam rangka mendukung pendidikan sepanjang hayat. Salah satu program PNF yang berperan sebagai pengganti adalah Pendidikan Kesetaraan. Di Indonesia, program PNF pendidikan kesetaraan ditekankan pada penguasaan pengetahuan dan keterampilan fungsional serta pengembangan sikap dan kepribadian professional. Selanjutnya, melalui proses penyetaraan, lulusan PNF dihargai setara dengan pendidikan formal. Selain akses, peningkatan mutu juga menjadi prioritas PNFI. Meskipun pemerintah telah melakukan berbagai program peningkatan, peningkatan kompetensi Pendidik dan Tenaga Kependidikan (PTK) dirasakan belum optimal terutama dalam upaya peningkatan mutu. Dilatarbelakangi permasalahan tersebut, penelitian ini dilakukan dengan tujuan mengidentifikasi berbagai kompetensi para PTK pendidikan kesetaraan saat ini maupun kompentensi yang diperlukan sesuai dengan standar yang ditetapkan. 
Permasalahan yang ada yaitu belum diketahuinya kebutuhan pelatihan para PTK PNF yang sesuai dengan kebutuhan mereka dalam melaksanakan tugas dan fungsinya. Adapun tujuan umum studi ini dimaksudkan untuk menyiapkan bahan rumusan kebijakan dalam rangka memberikan masukan terkait dengan kebutuhan pelatihan bagi para PTKPNF dalam upaya meningkatkan kompetensi mereka agar dapat melaksanakan tugas dan fungsinya secara optimal. Secara khusus, tujuan studi ini dimaksudkan untuk mendapatkan data dan informasi tentang: 1) Tingkat kompetensi PTKPNF; 2) Tingkat pengetahuan PTKPNF tentang SNP; dan 3) Faktor-faktor yang erat kaitannya dengan tingkat kompetensi PTKPNF.

\section{Kajian Pustaka}

\section{Pendidik dan Tenaga Kependidikan pada Pendidikan Non-formal (PTK-PNF)}

Pendidikan non-formal adalah jalur pendidikan di luar pendidikan formal yang dapat dilaksanakan secara terstruktur dan berjenjang dan berfungsi untuk mengembangkan potensi peserta didik dengan penekanan pada pengetahuan akademik dan keterampilan fungsional serta pengembangan sikap dan kepribadian professional.

Tenaga kependidikan nonformal adalah tenaga kerja yang menangani pendidikan non formal yang bertugas merencanakan dan melaksanakan proses pembelajaran. Kegiatan pembelajaran melibatkan unsur tenaga kependidikan dan unsur peserta didik (WB) yang dididik. Dalam Pedoman Pemetaan Kompetensi PTK-PNF terdiri dari 10 macam, 4 di antaranya yang terkait dengan studi ini yaitu: 1) pamong belajar adalah Pendidik PNF yang berstatus pegawai negeri sipil (PNS) yang berada di unit pelaksana teknis (UPT) pusat dan UPT Daerah dan satuan PNFI yang bertugas untuk melaksanakan kegiatan belajar mengajar, mengkaji program, dan pengembangan model PNFI; 2) penilik adalah tenaga kependidikan PNF yang berstatus pegawai negeri sipil (PNS) bertugas untuk melaksanakan pengendalian mutu program pendidikan nonformal dan informal (PNFI) melalui kegiatan pemantauan, penilaian, pembimbingan dan pembinaan serta evaluasi dampak program PNFI di tingkat kabupaten/kota; 3) Tutor Kesetaraan adalah tenaga yang berasal dari masyarakat yang bertugas dalam merencanakan, melaksanakan, mengevaluasi proses pembelajaran pada pendidikan kesetaraan; dan 4) Pengelola PKBM adalah ketua PKBM, sekretaris dan bendahara yang diberikan tugas dan kewenangan mengelola penyelenggaraan pusat kegiatan belajar masyarakat.

Keberhasilan pelaksanaan kegiatan pembelajaran di lingkungan pendidikan nonformal akan sangat ditentukan oleh kompetensi dan ketersediaan tenaga kependidikan nonformal. Ketersedian bisa dilihat dari jumlah tenaga kependidikan yang ada, kualifikasi tenaga kependidikan, lama mengajar, dan usia. Semakin banyak tenaga kependidikan nonformal yang tersedia dengan kualifikasi yang memadai dan semakin berpengalaman mereka, semakin baik kualitas kegiatan pembelajaran nonformal tersebut.

Dalam kajian ini PTK-PNF dibatasi pada tutor kesetaraan untuk program paket $A$ dan paket $B$. Tutor Kesetaraan dalam pedoman pemetaan kompetensi PTK-PNF melalui LPMP adalah tenaga yang berasal dari masyarakat yang bertugas dalam merencanakan, melaksanakan, mengevaluasi proses pembelajaran pada pendidikan kesetaraan.

\section{Program Pendidikan Kesetaraan}

Salah satu program Pendidikan Non Formal adalah Program Pendidikan Kesetaraan, yang meliputi program Kelompok belajar paket A setara SD, Kelompok Belajar paket B setara SMP dan Kelompok Belajar paket C setara SMA. Pendidikan non formal yang difokuskan dalam penelitian ini adalah program pendidikan kesetaraan. Berkaitan dengan program penuntasan wajib belajar 9 tahun, maka dalam penelitian ini program kesetaraan dibatasi pada program paket $A$ dan paket B. Pengertian paket A pendidikan kesetaraan dalam pedoman pembelajaran pendidikan kesetaraan adalah program pendidikan dasar pada jalur pendidikan nonformal yang dapat diikuti oleh peserta didik yang ingin menyelesaikan pendidikan setara SD/MI. Lulusan program paket A berhak mendapat ijazah dan diakui setara dengan ijazah SD/MI. Sedangkan pengertian program paket $B$ adalah program pendidikan dasar pada jalur pendidikan nonformal yang 
dapat diikuti oleh peserta didik yang ingin menyelesaikan pendidikan setara SMP/MTs. Lulusan program paket B berhak mendapat ijazah dan diakui setara dengan ijazah SMP/MTs.

\section{Mutu Pendidikan}

Dalam dokumen Education for All (EFA) global monitoring report, UNESCO (2005) menggarisbawahi bahwa capaian dari partisipasi universal dalam pendidikan secara fundamental tergantung pada kualitas pendidikan. Definisi kualitas pendidikan yang dirumuskan oleh UNESCO (2005) mengalami perkembangan. Pada deklarasi pendidikan untuk semua (EFA) tahun 1990an, UNESCO belum memiliki definisi yang jelas mengenai kualitas pendidikan. Pengertian lebih jelas, nampak dalam Kerangka Aksi Dakar (the Dakar Framework for Action), pada dokumen Learning to Be: The World of Education Today and Tomorrow, pada dokumen Learning: The Treasure Within. Akhirnya pada Table on Quality of Education di Paris pada tahun 2003, UNESCO menetapkan akses terhadap kualitas pendidikan sebagai hak asasi manusia (Pigozzi, 2004 dalam UNESCO, 2005). Pengertian mutu juga didefinisikan sebagai human capital, pendidikan merupakan unsur yang memainkan peranan penting dan signifikan dalam pertumbuhan ekonomi, sehingga pengeluaran pendidikan diperhitungkan sebagai bentuk investasi (Olanivan \& Okemakinde, 2008). Konsep pendidikan sebagai human capital memiliki kaitan erat dengan konsep efektivitas dan peningkatan sekolah. Hargreaves (2001) mencoba mengintegrasikan konsep-konsep tersebut menjadi sebuah konsep model yang memiliki empat master konsep yaitu: outcome, leverage, modal intelectual, dan modal sosial. Berdasarkan diskusi tersebut, terdapat dua konsep mutu pendidikan yang berbeda, antara perumusan UNESCO dan perumusan teori human kapital yang cenderung digunakan oleh Bank Dunia dalam mendefinisikan mutu pendidikan. Namun demikian, pada dasarnya dalam implementasinya saling menunjang, yaitu mutu pendidikan ditujukan untuk meningkatkan kehidupannya baik secara ekonomi, maupun hakekat kehidupan manusia.

\section{Mengukur Mutu Pendidikan}

Ukuran mutu pendidikan di sekolah mengacu pada derajat keunggulan setiap komponennya, bersifat relatif, dan selalu ada dalam perbandingan. Ukuran sekolah yang baik bukan semata-mata dilihat dari kesempurnaan komponennya dan kekuatan/ kelebihan yang dimilikinya, melainkan diukur pula dari kemampuan sekolah tersebut mengantisipasi perubahan, konflik, serta kekurangan atau kelemahan yang ada dalam dirinya.

Depdiknas mengemukakan paradigma mutu dalam konteks pendidikan, mencakup input, proses, dan output pendidikan (Depdiknas, 2006). Lebih jauh dijelaskan bahwa input pendidikan adalah segala sesuatu yang harus tersedia karena dibutuhkan untuk berlangsungnya proses, yang dimaksud sesuatu adalah berupa sumberdaya dan perangkat lunak serta harapan-harapan sebagai pemandu bagi keberlangsungan proses. Input sumberdaya meliputi sumberdaya manusia (seperti ketua, dosen, konselor, peserta didik) dan sumberdaya selebihnya (peralatan, perlengkapan, uang bahan-bahan, dan sebagainya). Input perangkat meliputi: struktur organisasi, peraturan perundang-undangan, deskripsi tugas, rencana, program, dan lain sebagainya. Input harapanharapan berupa visi, misi, tujuan dan sasaran yang ingin dicapai. Kesiapan input sangat diperlukan agar proses dapat berlangsung dengan baik. Dengan kata lain, dapat disimpulkan bahwa tinggi rendahnya mutu input dapat diukur dari tingkat kesiapan input, makin tinggi kesiapan input, makin tinggi pula mutu input tersebut. Proses pendidikan merupakan proses berubahnya sesuatu menjadi sesuatu yang lain. Sesuatu yang berpengaruh terhadap berlangsungnya proses disebut input, sedangkan sesuatu dari hasil proses disebut output. Proses dikatakan bermutu tinggi apabila peng-koordinasian dan penyerasian serta pemanduan input dilakukan secara harmonis, sehingga mampu menciptakan situasi pembe-lajaran yang menyenangkan (enjoyable learning), mampu mendorong motivasi dan minat belajar, dan benar-benar mampu memberdayakan peserta didik.

Dalam kajian ini mutu diukur melalui komponen guru dalam hal ini tutor di pendidikan non formal. Salah satu indikator yang dapat mengukur mutu tutor adalah kualifikasi akademik yang dimiliki. Dalam acuan proses pelaksanaan dan pembelajaran pendidikan kesetaraan 
program paket A, paket B dan paket C, syarat kualifikasi akademik yang harus dimiliki pendidik pada pendidikan kesetaraan adalah pendidikan minimal D-IV atau S1 dan yang sederajat untuk program paket A, paket B dan paket C. Namun, untuk daerah yang tidak memiliki sumberdaya manusia yang sesuai, pendidikan minimal DII dan yang sederajat untuk paket $A$ dan paket $B$, dan DIII untuk paket $C$.

\section{Kompetensi PTK-PNF}

Pengembangan profesionalisme pendidik dan tenaga kependidikan pendidikan nonformal (PTKPNF) yang telah dilakukan menggambarkan kondisi pendidik dan tenaga kependidikan yang ada di Indonesia saat ini. Agar pendidikan formal maupun nonformal bisa mencapai mutu akademik yang tinggi, maka harus didukung oleh PTK yang kompeten.

PTK-PNF dituntut untuk menguasai Standar Kompetensi, dengan pertimbangan beberapa kondisi sebagai berikut: 1 ) belum adanya keseragaman atau standarisasi tingkat kemampuan dan kualitas PTK-PNF, 2) belum adanya alat ukur yang akurat untuk mengetahui kompetensi PTK$P N F, 3)$ pengembangan kemampuan dan pembinaan yang dilakukan bagi PTK-PNF tidak berdasarkan pada apa yang perlu ditingkatkan, dan 4) masih rendahnya tingkat kesejahteraan para PTK-PNF.

Berdasarkan pasal 28 ayat (3) Peraturan Pemerintah Nomor 19 tahun 2005 tentang Standar Nasional Pendidikan, kompetensi sebagai agen pembelajaran pada jenjang pendidikan dasar dan menengah meliputi: Kompetensi Pedagogik, Kompetensi Kepribadian, Kompetensi professional, dan Kompetensi sosial. Definisi keempat kompetensi tersebut menurut berikut Standar Kompetensi PTK-PNF dan Sistem Penilaian (Depdiknas, 2006) adalah seperti berikut.

\section{Kompetensi Pedagogik}

Kompetensi pedagogik merupakan kemampuan yang berkenaan dengan pemahaman terhadap Warga Belajar (WB) dan pengelola pembelajaran yang mendidik dan dialogis. Secara substantif kompetensi ini mencakup kemampuan pemahaman terhadap peserta didik, perancangan dan pelaksanaan pembelajaran, memahami kurikulum, evaluasi hasil belajar, dan pengembangan peserta didik untuk mengaktualisasikan berbagai potensi yang dimilikinya

\section{Kompetensi Kepribadian}

Kompetensi kepribadian merupakan kemampuan personal yang mencerminkan kepribadian yang mantap, stabil, dewasa, arif, dan berwibawa, menjadi teladan bagi peserta didik/WB, dan berakhlak mulia. Secara rinci setiap elemen kepribadian tersebut dapat dijabarkan menjadi subkompetensi dan indikator esensial sebagai berikut: (i) Memiliki kepribadian yang mantap dan stabil; (ii) Memiliki kepribadian yang dewasa; (iii) Memiliki kepribadian yang arif; (iv) Memiliki kepribadian yang berwibawa; dan (v) Memiliki akhlak mulia dan dapat menjadi teladan.

\section{Kompetensi Profesional}

Kompetensi profesional merupakan kemampuan yang berkenaan dengan penguasaan materi pembelajaran secara luas dan mendalam yang mencakup penguasaan substansi isi materi kurikulum matapelajaran di satuan PNF dan substansi keilmuan yang menaungi materi kurikulum tersebut, serta menambah wawasan keilmuan sebagai PTK-PNF. Secara rinci masingmasing elemen kompetensi tersebut memiliki subkompetensi dan indikator esensial sebagai berikut: 1) Menguasai substansi keilmuan sosial dan ilmu lain yang terkait bidang studi; dan 2) Menguasai langkah-langkah penelitian dan kajian kritis untuk menambah wawasan dan memperdalam pengetahuan/materi pembelajaran.

\section{Kompetensi Sosial}

Kompetensi sosial berkenaan dengan kemampuan pendidik sebagai bagian dari masyarakat untuk berkomunikasi dan bergaul secara efektif dengan peserta didik/WB, sesama pendidik, tenaga kependidikan, orangtua/wali peserta didik/WB, dan masyarakat sekitar. Kompetensi ini memiliki subkompetensi dengan indikator esensial sebagai berikut: 1) Mampu berkomunikasi dan bergaul secara efektif dengan peserta didik/WB, baik lisan maupun tulisan; 2) Mampu berkomunikasi dan bermitra secara efektif dengan sesama pendidik dan tenaga kependidikan; dan 3) Mampu berkomunikasi dan 
bermitra secara efektif dengan orang tua/wali peserta didik/WBdan masyarakat sekitar, sesuai dengan kebudayaan dan adat istiadat.

\section{Metodologi Penelitian}

Pendekatan yang digunakan dalam penelitian ini yaitu pendekatan kualitatif dengan dukungan data kuantitatif.

\section{Populasi dan sampel}

Populasi penelitian ini adalah seluruh kelompok belajar (kejar) Paket A dan Paket B di seluruh Indonesia. Data memperlihatkan bahwa jumlah kejar Paket A setara SD pada kurun waktu 1 Januari sampai dengan 30 Desember 2009 sebanyak 5.424 kejar, sedangkan jumlah kejar Paket B setara SMP sebanyak 14.322 kejar. Di dalam kelompok belajar terdapat pengelola, tutor, dan warga belajar. Secara lengkap jumlah jumlah masing-masing untuk kurun waktu yang sama tampak pada Tabel 1 berikut.

Pemilihan sampel provinsi dilakukan secara purposive, dengan kriteria provinsi tersebut adalah lokasi P2PNFI atau BPPNFI atau provinsi binaan P2PNFI atau BPPNFI yang memiliki BPKB. Jumlah sampel provinsi sebanyak 8 provinsi sebagai berikut: 1) Provinsi Sumatera Selatan (memiliki BPKB dan wilayah kerja BPPNFI Regional; 2) Provinsi Lampung (memiliki BPKB dan wilayah kerja P2PNFI Regional II); 3) Provinsi Jawa Barat (P2PNFI Regional II); 4) Provinsi Jawa Timur (BPPNFI Regional IV); 5) Provinsi Sulawesi Selatan (BPPNFI Regional V); 6) Provinsi Kalimantan Selatan (BPPNFI Regional VI); 7) Provinsi Nusa Tenggara Barat (BPPNFI Regional VII); dan 8) Provinsi Maluku (memiliki BPKB dan wilayah kerja BPPNFI Regional VIII).

Di setiap provinsi sampel diambil 1 kabupaten dan 1 kota. Kabupaten/kota pilihan pertama adalah kabupaten/kota lokasi P2PNFI atau BPPNFI atau BPKB. Pemilihan kabupaten/kota kedua menggunakan kriteria sebagai daerah yang menjadi ujicoba KTSP sehingga diperkirakan sudah menggunakan KTSP. Sampel kabupaten/ kota adalah sebagai berikut: Sumatera Selatan (Kota Palembang, Kabupaten Ogan Ilir), Lampung

Tabel 1. Jumlah Pengelola, Tutor, dan Warga Belajar pada tahun 2009

\begin{tabular}{|c|l|c|c|}
\hline \multirow{2}{*}{ No. } & \multirow{2}{*}{ Komponen } & \multicolumn{2}{|c|}{ Jumlah (orang) } \\
\cline { 3 - 4 } & & Paket A setara SD & Paket B setara SMP \\
\hline 1. & Pengelola & 10.993 & 29.893 \\
\hline 2. & Tutor & 19.247 & 104.857 \\
\hline 3. & Warga belajar & 149.476 & 573.581 \\
\hline
\end{tabular}

Tabel 2. Sampel Responden Penelitian

\begin{tabular}{|c|c|c|c|}
\hline $\begin{array}{c}\text { Sampel } \\
\text { Responden }\end{array}$ & Kelompok & Jenis & Keterangan \\
\hline \multirow{5}{*}{ Pendidik } & \multirow[t]{2}{*}{ Tutor } & Tutor Paket A & \multirow[t]{2}{*}{ Di Kejar dan di PKBM } \\
\hline & & Tutor Paket B & \\
\hline & \multirow{3}{*}{$\begin{array}{l}\text { Pamong Belajar } \\
\text { Kesetaraan }\end{array}$} & P2PNFI atau BPPNFI & Lembaga pusat di daerah \\
\hline & & BPKB & Lembaga provinsi \\
\hline & & SKB & Lembaga kabupaten/kota \\
\hline \multirow{3}{*}{$\begin{array}{l}\text { Tenaga } \\
\text { Kepen- } \\
\text { didikan }\end{array}$} & \multirow[t]{2}{*}{$\begin{array}{l}\text { Pengelola } \\
\text { program Paket } \\
\text { A dan/Paket B. }\end{array}$} & $\begin{array}{l}\text { Di Kejar penyeleng-gara } \\
\text { program Paket A dan/ } \\
\text { Paket B. }\end{array}$ & \multirow{2}{*}{$\begin{array}{l}\text { Kejar biasanya dibina oleh } \\
\text { SKB, sementara PKBM di- } \\
\text { bina oleh Dinas Pendidikan } \\
\text { Kabupaten/kota. }\end{array}$} \\
\hline & & $\begin{array}{l}\text { Di penyelenggara } \text { PKBM } \\
\text { program Paket A dan/ } \\
\text { Paket B. }\end{array}$ & \\
\hline & Penilik PLS & & $\begin{array}{l}\text { Baik yang berkedudukan di } \\
\text { Dinas Pendidikan Kabupa- } \\
\text { ten/kota maupun yang di } \\
\text { tingkat kecamatan. }\end{array}$ \\
\hline
\end{tabular}


(Kota Bandar Lampung, Kabupaten Lampung Barat), Jawa Barat (Kota Bandung, Kabupaten Bandung), Jawa Timur (Kota Surabaya, Kabupaten Pamekasan), Kalimantan Barat (Kota Pontianak, Kabupaten Pontianak), Sulawesi Selatan (Kota Makassar, Kabupaten Bone), Nusa Tenggara Barat (Kota Mataram, Kabupaten Dompu), dan Maluku (Kota Ambon, Maluku Tengah). Sampel responden secara lengkap dapat dilihat di Tabel 2.

\section{Teknik Pengumpulan Data}

Pengumpulan data dilakukan melalui tes, wawancara, dan penilaian teman sejawat. Rincian tes untuk Tutor Paket A, Tutor Paket B, dan pengelola tampak pada Tabel 3 .

Untuk mengetahui kompetensi profesional dan pedagogik mereka, pamong belajar diminta untuk melakukan penilaian diri. Kompetensi kepribadian dan kompetensi sosial pamong belajar diperoleh melalui penilaian teman sejawat. Secara lengkap alokasi responden per kabupaten/ kota menurut teknik pengumpulan datanya tampak di Tabel 4.

\section{Analisis Data}

Analisis data akan dilakukan secara deskriptif, baik secara kualitatif maupun kuantitatif. Setelah diketahui kompetensi PTK program Paket A dan Paket $B$ saat dilakukan pengumpulan data dan kompetensi yang dibutuhkan sesuai kondisi saat ini, maka kebutuhan pelatihan mereka dapat ditemukan.

\section{Hasil Penelitian dan dan Pembahasan Tingkat Kompetensi PTK PNF}

PTK PNF yang disampaikan kompetensinya di sini meliputi tutor Paket A, tutor Paket B, pamong belajar, dan pengelola kejar Paket $\mathrm{A}$ dan atau Paket B.

\section{Tutor Paket A dan Tutor Paket B}

Nilai terendah yang dicapai oleh Tutor Paket $A$ dan Tutor Paket B yaitu untuk kompetensi pedagogik, dan tertinggi untuk kompetensi kepribadian (Lihat Gambar 1 dan 2). Kompetensi profesional Tutor Paket A dan Tutor Paket B masih rendah, rerata nilai yang dicapai sebesar 40 dan 50,7 dari 100 .

Tabel 3. Rincian Tes Tutor dan Pengelola Kejar Paket A dan Paket B

\begin{tabular}{|c|c|}
\hline \multicolumn{2}{|c|}{ Tes Tutor Paket $\mathrm{A}$} \\
\hline $\begin{array}{l}\text { Menggunakan soal tes WB(WB) Paket } \\
\text { A dan Paket B yang sulit saja }\end{array}$ & $\begin{array}{l}\text { Alasan: Kualifikasi pendidikan tutor Paket A } \\
\text { (menurut pedoman) adalah SMA, sementara } \\
\text { kualifikasi pendidikan guru SD formal S1. }\end{array}$ \\
\hline $\begin{array}{l}\text { Satu buku soal terdiri atas } 5 \text { mata } \\
\text { pelajaran (total } 90 \text { soal) }\end{array}$ & $\begin{array}{l}\text { Pendidikan Kewarganegaraan (PKn) (15 soal) } \\
\text { Bahasa Indonesia ( } 25 \text { soal) } \\
\text { Matematika ( } 15 \text { soal) } \\
\text { IPA ( } 20 \text { soal) } \\
\text { IPS ( } 15 \text { soal) }\end{array}$ \\
\hline Waktu tes & 120 menit \\
\hline \multicolumn{2}{|c|}{ Tes Tutor Paket B } \\
\hline $\begin{array}{l}\text { Menggunakan soal tes WB(WB) Paket } \\
\text { B dan Paket C yang sulit saja. }\end{array}$ & $\begin{array}{l}\text { Alasan: Kualifikasi pendidikan tutor Paket A } \\
\text { (menurut pedoman) adalah SMA, sementara } \\
\text { kualifikasi pendidikan guru SD formal S1. }\end{array}$ \\
\hline Jumlah soal = paket utuh. & $\begin{array}{l}\text { Pendidikan Kewarganegaraan (PKn) (50 soal) } \\
\text { Bahasa Indonesia ( } 50 \text { soal) } \\
\text { Matematika ( } 40 \text { soal) } \\
\text { IPA ( } 50 \text { soal) } \\
\text { IPS ( } 50 \text { soal) }\end{array}$ \\
\hline $\begin{array}{l}\text { Waktu tes untuk setiap mata pela- } \\
\text { jaran. }\end{array}$ & 90 menit. \\
\hline \multicolumn{2}{|c|}{ Tes Pengelola Kejar Paket A dan/ Paket B } \\
\hline Tes kompetensi & $\begin{array}{l}\text { Kompetensi manajerial ( } 30 \text { soal) } \\
\text { Kompetensi kepribadian ( } 10 \text { soal) } \\
\text { Kompetensi sosial ( } 10 \text { soal) }\end{array}$ \\
\hline Waktu tes & 60 menit \\
\hline
\end{tabular}


Tabel 4. Alokasi Responden per Kabupaten/kota

\begin{tabular}{|c|c|c|c|c|c|}
\hline ว. & $\begin{array}{l}\text { Sumber } \\
\text { data/responden }\end{array}$ & Wawancara & Tes/kuesioner & $\begin{array}{l}\text { Menilai teman } \\
\text { sejawat }\end{array}$ & Keterangan \\
\hline . & $\begin{array}{l}\text { Kelompok } \\
\text { belajar Paket A }\end{array}$ & & & & $\begin{array}{l}\text { Kalau sudah mendapat } \\
\text { kejar Paket A/B, kejar } \\
\text { lainnya boleh Paket A } \\
\text { atau Paket B. Kejar } \\
\text { yang d bukan i SKB }\end{array}$ \\
\hline - & $\begin{array}{l}\text { Pengelola kejar } \\
\text { Paket A }\end{array}$ & 1 & $\begin{array}{l}5 \text { (dari beberapa } \\
\text { kejar/PKBM) }\end{array}$ & - & $\begin{array}{l}\text { Kalau sudah mendapat } \\
\text { pengelola kejar Paket } \\
\text { A/B, pengelola kejar } \\
\text { lainnya boleh Paket A } \\
\text { atau Paket B. }\end{array}$ \\
\hline . & Tutor Paket A & 2 & $\begin{array}{c}10 \text { (dari beberapa } \\
\text { kejar) }\end{array}$ & - & $\begin{array}{l}2 \text { tutor dari kelompok } \\
\text { belajar yang berbeda }\end{array}$ \\
\hline . & $\begin{array}{l}\text { Kelompok } \\
\text { belajar Paket B }\end{array}$ & & & & $\begin{array}{c}\text { Kejar yang bukan di } \\
\text { SKB }\end{array}$ \\
\hline 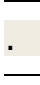 & $\begin{array}{l}\text { Pengelola kejar } \\
\text { Paket B }\end{array}$ & 1 & $\begin{array}{c}5 \text { (dari beberapa } \\
\text { kejar) }\end{array}$ & - & \\
\hline . & Tutor Paket B & 2 & $\begin{array}{l}12 \text { (dari beberapa } \\
\text { kejar/PKBM) utk } 6 \\
\text { mata pelajaran }\end{array}$ & - & $\begin{array}{l}2 \text { tutor dari kelompok } \\
\text { belajar yang berbeda }\end{array}$ \\
\hline . & $\begin{array}{l}\text { Pamong belajar } \\
\text { SKB (lembaga } \\
\text { kabupaten/kota } \\
\text { ) }\end{array}$ & $\begin{array}{l}\text { 1(ketua } \\
\text { pokja) }\end{array}$ & $\begin{array}{l}\text { Semua anggota } \\
\text { Pokja } \\
\text { kesetaraan/program } \\
\text { studi }\end{array}$ & $\begin{array}{l}\text { Semua anggota } \\
\text { Pokja } \\
\text { kesetaraan/ } \\
\text { program studi }\end{array}$ & \\
\hline . & Penilik PLS & 2 & & & $\begin{array}{l}\text { Penilik yang membina } 2 \\
\text { kejar sumber data }\end{array}$ \\
\hline \multicolumn{6}{|c|}{ Lembaga Provinsi } \\
\hline$\cdot$ & $\begin{array}{l}\text { Pamong belajar } \\
\text { BPKB (lembaga } \\
\text { provinsi) }\end{array}$ & $\begin{array}{l}\text { 1(ketua } \\
\text { pokja) }\end{array}$ & $\begin{array}{l}\text { Semua anggota } \\
\text { Pokja } \\
\text { kesetaraan/program } \\
\text { studi }\end{array}$ & $\begin{array}{l}\text { Semua anggota } \\
\text { Pokja } \\
\text { kesetaraan/ } \\
\text { program studi }\end{array}$ & $\begin{array}{c}\text { E atau F disesuaikan dg } \\
\text { lokasi }\end{array}$ \\
\hline \multicolumn{6}{|c|}{ Lembaga Pusat } \\
\hline$\cdot$ & $\begin{array}{l}\text { Pamong belajar } \\
\text { P2PNFI/BPPNFI } \\
\text { (lembaga pusat } \\
\text { di daerah) }\end{array}$ & $\begin{array}{l}1 \text { (ketua } \\
\text { pokja) }\end{array}$ & $\begin{array}{l}\text { Semua anggota } \\
\text { Pokja } \\
\text { kesetaraan/program } \\
\text { studi }\end{array}$ & $\begin{array}{l}\text { Semua anggota } \\
\text { Pokja } \\
\text { kesetaraan/ } \\
\text { program studi }\end{array}$ & \\
\hline
\end{tabular}

Hal itu mencerminkan bahwa program kesetaraan dilakukan dengan ketersediaan sumberdaya yang seadanya, yang penting adalah program yang direncanakan dapat dilaksanakan meskipun dengan berbagai keterbatasan, termasuk keterbatasan kompetensi penguasaan substansi.

Kriteria penilaian tampak pada Tabel 4. Rendahnya nilai kompetensi pedagogik

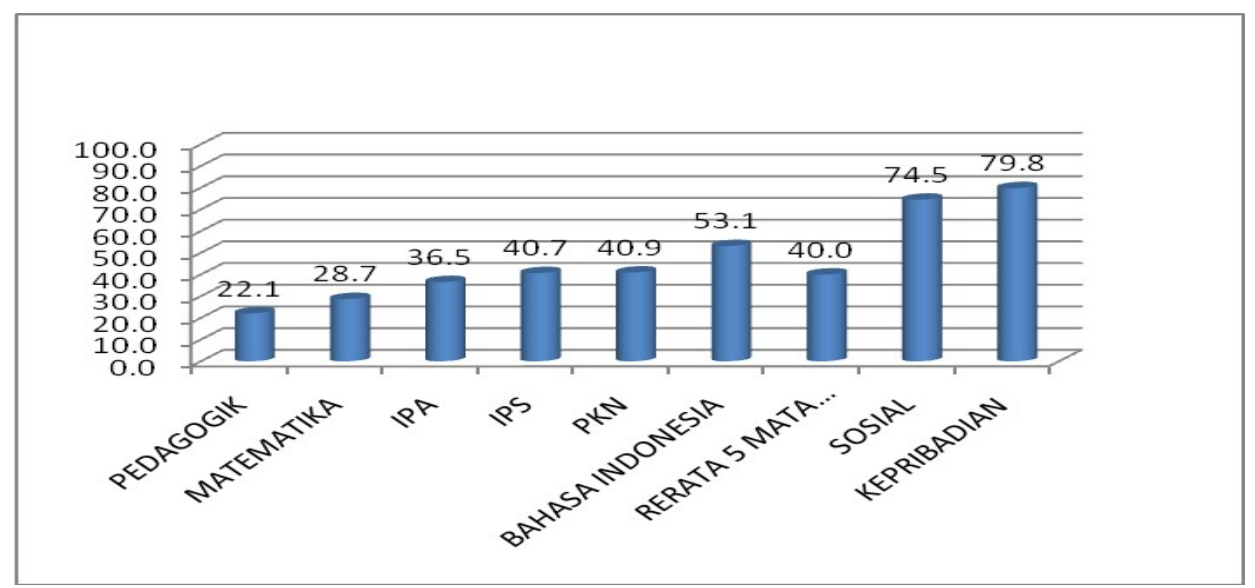

Gambar 1. Nilai Rerata Kompetensi Tutor Paket A 


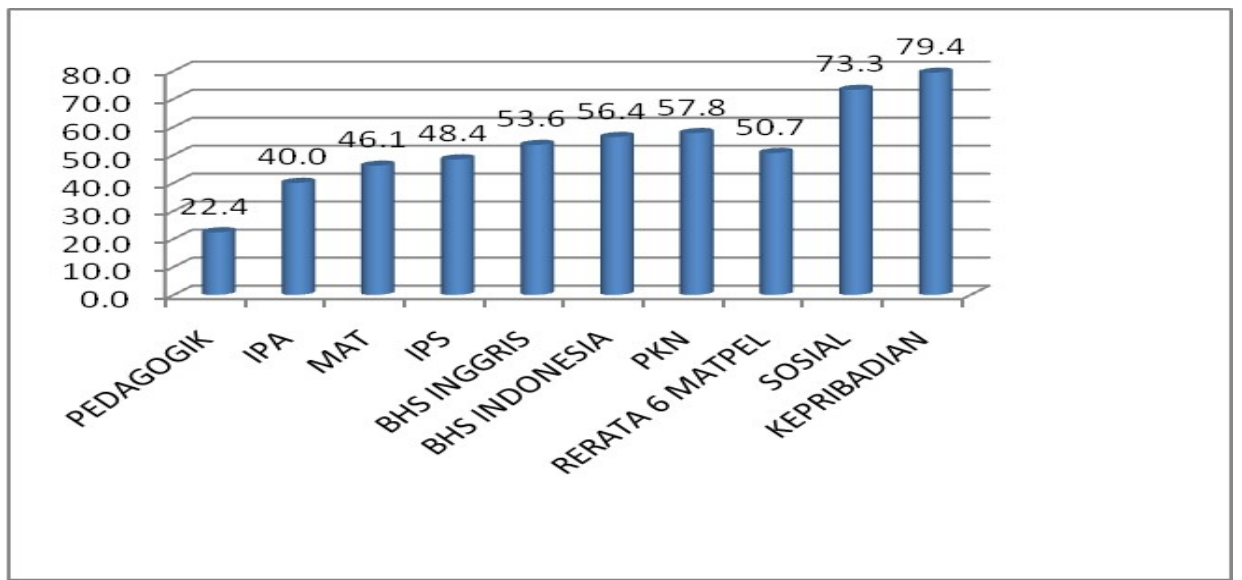

Gambar 2. Nilai Rerata Kompetensi Tutor Paket B

kemungkinan disebabkan oleh tingkat pendidikan Tutor Paket A yang hanya SMA (29 persen dari responden yang diwawancarai) dan Tutor Paket B yang D3 (sebanyak 24 persen responden yang diwawancarai) sehingga tidak memiliki pengetahuan yang cukup tentang pedagogik dan kurangnya pelatihan dengan materi pedagogik. Di antara tutor Paket A cukup banyak yang sudah memperoleh pelatihan, tetapi pelatihan yang mereka terima tidak selalu spesifik terkait langsung dengan pendidikan kesetaraan Paket A, melainkan materi pendidikan non-formal.

Mengacu ke kriteria, maka hanya 5,88 persen tutor Paket A yang kompeten. Di antara 5,88 persen tersebut sebanyak 4,90 persen untuk mata pelajaran Bahasa Indonesia dan 0,98 persen untuk pelajaran IPS (lihat Tabel 5). Proporsi Tutor Paket B yang kompeten sebanyak 23,94

Tabel 5. Kriteria Penilaian dan Kategori Pencapaian Nilai Rerata Tutor Paket A dan Tutor Paket B

\begin{tabular}{|c|c|c|c|c|c|c|}
\hline \multirow[b]{2}{*}{ No. } & \multirow[b]{2}{*}{ Kompetensi } & \multirow[b]{2}{*}{ Mata Pelajaran } & \multicolumn{2}{|c|}{ Kriteria } & \multicolumn{2}{|c|}{ Pencapaian Nilai } \\
\hline & & & Nilai & Kategori & $\begin{array}{l}\text { Tutor } \\
\text { Paket A }\end{array}$ & $\begin{array}{l}\text { Tutor } \\
\text { Paket B }\end{array}$ \\
\hline \multirow{6}{*}{1.} & \multirow{6}{*}{ Profesional } & $\mathrm{PKn}$ & \multirow{6}{*}{$\geq 80$} & \multirow{6}{*}{$\begin{array}{c}\text { Kompe- } \\
\text { ten }\end{array}$} & \multirow{6}{*}{$\begin{array}{l}\text { Belum } \\
\text { kompe- } \\
\text { ten }\end{array}$} & $\begin{array}{l}\text { Belum } \\
\text { kompeten }\end{array}$ \\
\hline & & Bhs.Indonesia & & & & $\begin{array}{l}\text { Belum } \\
\text { kompeten }\end{array}$ \\
\hline & & Matematika & & & & $\begin{array}{l}\text { Belum } \\
\text { kompeten }\end{array}$ \\
\hline & & IPA & & & & $\begin{array}{l}\text { Belum } \\
\text { kompeten }\end{array}$ \\
\hline & & IPS & & & & $\begin{array}{l}\text { Belum } \\
\text { kompeten }\end{array}$ \\
\hline & & Bhs.Inggris & & & & $\begin{array}{l}\text { Belum } \\
\text { kompeten }\end{array}$ \\
\hline 2. & \multicolumn{2}{|c|}{ Pedagogik } & $\geq 80$ & $\begin{array}{c}\text { Kompe- } \\
\text { ten }\end{array}$ & $\begin{array}{l}\text { Belum } \\
\text { kompe- } \\
\text { ten }\end{array}$ & $\begin{array}{c}\text { Belum } \\
\text { kompeten }\end{array}$ \\
\hline \multirow{3}{*}{3.} & \multirow{3}{*}{\multicolumn{2}{|c|}{ Kepribadian }} & $<25$ & Rendah & & \\
\hline & & & $\begin{array}{r}\geq 25 \\
-75 \\
\end{array}$ & Sedang & & \\
\hline & & & $\geq 76$ & Tinggi & Tinggi & Tinggi \\
\hline \multirow{3}{*}{4.} & \multirow{3}{*}{\multicolumn{2}{|c|}{ Sosial }} & $<25$ & Rendah & & \\
\hline & & & $\begin{array}{l}\geq 25 \\
75\end{array}$ & Sedang & Sedang & Sedang \\
\hline & & & $\geq 76$ & Tinggi & & \\
\hline
\end{tabular}


Tabel 6. Sebaran Nilai Tutor Paket A untuk 5 Mata Pelajaran

\begin{tabular}{|c|c|c|c|c|c|c|c|c|c|c|}
\hline \multirow{2}{*}{$\begin{array}{c}\text { Kisaran } \\
\text { Nilai }\end{array}$} & \multicolumn{9}{|c|}{ MATA PELAJARAN } \\
\cline { 2 - 13 } & $\begin{array}{c}|c| \\
\text { Pumlah } \\
\text { (org) }\end{array}$ & $\%$ & $\begin{array}{c}\text { Bahasa } \\
\text { Indonesia } \\
\text { (org) }\end{array}$ & $\%$ & $\begin{array}{c}\text { Jumlah } \\
\text { (org) }\end{array}$ & $\%$ & $\begin{array}{c}\text { Jumlah } \\
\text { (org) }\end{array}$ & $\%$ & $\begin{array}{c}\text { Jumlah } \\
\text { (org) }\end{array}$ & $\%$ \\
\hline $0-20$ & 13 & 12,75 & 15 & 14,71 & 39 & 38,24 & 20 & 19,61 & 23 & 22,55 \\
\hline $21-40$ & 44 & 43,14 & 7 & 6,86 & 48 & 47,06 & 39 & 38,24 & 25 & 24,51 \\
\hline $41-60$ & 40 & 39,22 & 39 & 38,24 & 10 & 9,80 & 33 & 32,35 & 38 & 37,25 \\
\hline $61-79$ & 5 & 4,90 & 36 & 35,29 & 5 & 4,90 & 10 & 9,80 & 15 & 14,71 \\
\hline $80-100$ & 0 & 0 & 5 & 4,90 & 0 & 0 & 0 & 0 & 1 & 0,98 \\
\hline Jumlah & 102 & 100 & 102 & 100 & 102 & 100 & 102 & 100 & 102 & 100 \\
\hline
\end{tabular}

persen (lihat Tabel 6). Di antara 23,94 persen, sebanyak 10,34 persen kompeten dalam pelajaran PKn, 4,90 persen kompeten dalam pelajaran Bahasa Indonesia, dan 8,70 persen kompeten dalam pelajaran Matematika.

Berdasarkan hasil tes tersebut, maka kompetensi Tutor Paket A dan Paket B dalam penguasaan materi mata pelajaran serta pedagogik perlu ditingkatkan. Selain itu, perlu diupayakan untuk meningkatkan tingkat pendidikan Tutor Paket A minimal D2 dan Tutor Paket B minimal D3.

\section{Pamong Belajar}

Hasil tes ini bukan menggambarkan 4 kompetensi, namun merupakan pengetahuan tentang 4 kompetensi. Gambaran kompetensi pedagogik tutor yang dinilai dengan tes baru sebatas pengetahuan pedagogik belum pada kemampuan pedagogiknya. Kriteria penilaian tampak pada Tabel 7 , sedangkan nilainya dapat dilihat pada Tabel 8.

Rerata nilai kompetensi profesional pamong belajar termasuk kategori tinggi. Kompetensi profesional Pamong belajar dengan frekuensi

Tabel 7. Sebaran Nilai Tutor Paket B untuk 5 Mata Pelajaran

\begin{tabular}{|c|c|c|c|c|c|c|c|c|c|c|c|c|}
\hline \multirow{3}{*}{$\begin{array}{c}\text { Kisa- } \\
\text { ran } \\
\text { Nilai }\end{array}$} & \multicolumn{10}{|c|}{ MATA PELAJARAN } & & \\
\hline & \multicolumn{2}{|c|}{ PKn } & \multicolumn{2}{|c|}{ Bahasa Indonesia } & \multicolumn{2}{|c|}{ Matematika } & \multicolumn{2}{|c|}{ IPA } & \multicolumn{2}{|r|}{ IPS } & \multicolumn{2}{|c|}{ Bahasa Inggris } \\
\hline & $\begin{array}{l}\text { Juml } \\
\text { ah } \\
\text { (org) }\end{array}$ & $\begin{array}{c}\text { Persenta } \\
\text { se }\end{array}$ & $\begin{array}{l}\text { Jumlah } \\
\text { (org) }\end{array}$ & Persentase & $\begin{array}{l}\text { Jumlah } \\
\text { (org) }\end{array}$ & Persentase & $\begin{array}{l}\text { Jumlah } \\
\text { (org) }\end{array}$ & Persentase & $\begin{array}{c}\text { Jumlah } \\
\text { (org) }\end{array}$ & Persentase & $\begin{array}{l}\text { Jumlah } \\
\text { (org) }\end{array}$ & $\begin{array}{c}\text { Persentas } \\
\text { e }\end{array}$ \\
\hline $0-20$ & 1 & 3,45 & 15 & 14,71 & 1 & 4,35 & 0 & 0 & 0 & 0 & 0 & 0 \\
\hline $21-40$ & 4 & 13,79 & 7 & 6,86 & 11 & 47,83 & 13 & 54,17 & 7 & 29,17 & 5 & 20,83 \\
\hline $41-60$ & 10 & 34,48 & 39 & 38,24 & 5 & 21,74 & 10 & 41,67 & 14 & 58,33 & 10 & 58,33 \\
\hline $61-79$ & 11 & 37,93 & 36 & 35,29 & 4 & 17,39 & 1 & 4,17 & 3 & 12,50 & 8 & 33,33 \\
\hline $\begin{array}{l}80- \\
100 \\
\end{array}$ & 3 & 10,34 & 5 & 4,90 & 2 & 8,70 & 0 & 0 & 0 & 0 & 0 & 0 \\
\hline $\begin{array}{c}\text { Jumla } \\
\mathrm{h}\end{array}$ & 29 & 100 & 102 & 100 & 23 & 100 & 24 & 100 & 24 & 100 & 23 & 100 \\
\hline
\end{tabular}

Tabel 8. Kriteria Nilai Kompetensi Profesional, Pedagogik, Kepribadian, dan Sosial Pamong Belajar

\begin{tabular}{|c|c|c|}
\hline No. & Nilai & Kategori \\
\hline 1. & $-1,67$ & Rendah \\
\hline 2. & $>1,67-2,33$ & Sedang \\
\hline 3. & $>2,33-3$ & Tinggi \\
\hline
\end{tabular}

tertinggi (73,02 persen) adalah untuk kelompok nilai tinggi dicapai oleh Pamong Belajar SKB (lihat Gambar 4). Hal ini disebabkan pamong belajar SKB melaksanakan tugas keprofesian dengan frekuensi yang lebih tinggi dibandingkan Pamong belajar di P3PNFI dan BPPNFI serta BPKB. Hal itu cenderung disebabkan oleh adanya perma- 
Tabel 9. Rerata Nilai Kompetensi Pamong Belajar

\begin{tabular}{|c|l|c|c|c|c|c|c|c|c|c|c|c|c|}
\hline \multirow{2}{*}{ No. } & \multirow{10}{*}{ Lembaga } & \multicolumn{10}{|c|}{ Kompetensi } \\
\cline { 4 - 13 } & & \multicolumn{2}{|c|}{ Profesional } & \multicolumn{1}{|c|}{ Pedagogik } & \multicolumn{2}{|c|}{ Kepribadian } & \multicolumn{3}{|c|}{ Sosial } \\
\hline & & $\mathrm{R}$ & $\mathrm{S}$ & $\mathrm{T}$ & $\mathrm{R}$ & $\mathrm{S}$ & $\mathrm{T}$ & $\mathrm{R}$ & $\mathrm{S}$ & $\mathrm{T}$ & $\mathrm{R}$ & $\mathrm{S}$ & $\mathrm{T}$ \\
\hline 1. & P2PNFI & & & $\sqrt{ }$ & & $\sqrt{ }$ & & & & $\sqrt{ }$ & & & $\sqrt{ }$ \\
\hline 2. & BPPNFI & & & $\sqrt{ }$ & & $\sqrt{ }$ & & & & $\sqrt{ }$ & & & $\sqrt{ }$ \\
\hline 3. & BPKB & & & $\sqrt{ }$ & & $\sqrt{ }$ & & & & $\sqrt{ }$ & & & $\sqrt{ }$ \\
\hline 4. & SKB & & & $\sqrt{ }$ & & & $\sqrt{ }$ & & & $\sqrt{ }$ & & & $\sqrt{ }$ \\
\hline
\end{tabular}

$\mathrm{R}$ : rendah $\mathrm{S}$ : sedang $\mathrm{T}$ : Tinggi

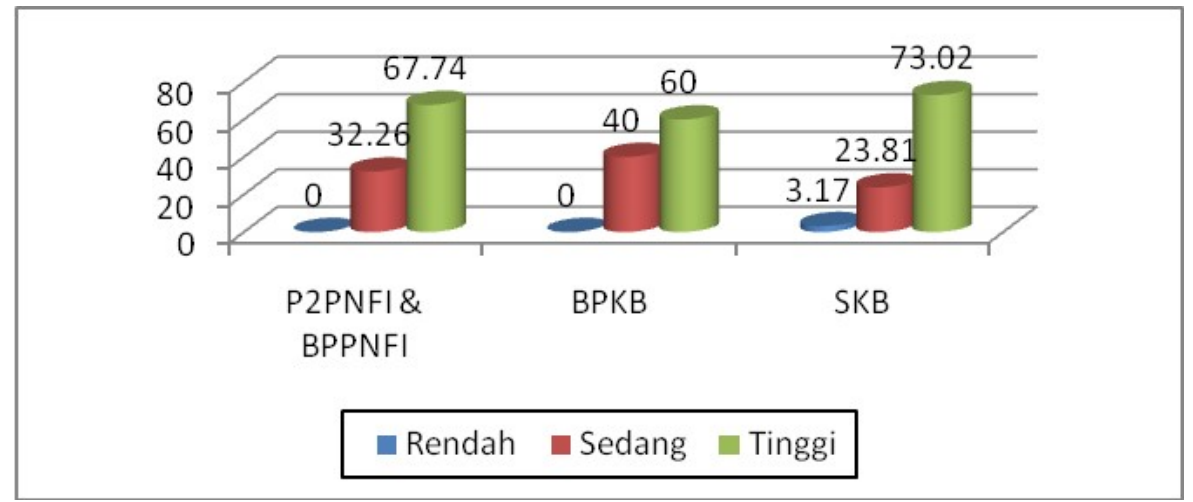

Gambar 4. Persentase Frekuensi Nilai Kompetensi Profesional Pamong Belajar

salahan terkait dengan tugas pokok dan fungsi (tupoksi) mereka masing-masing. Berdasarkan Permenpan No.15 tahun 2010 tentang Angka Kredit Jabatan Fungsional Pamong Belajar, tugas Pamong belajar adalah i) Melaksanakan pembelajaran; ii) melaksanakan pembimbingan; iii) Melaksanakan pelatihan; iv) Mengelola program PNF ; dan v) Mengembangkan model. Namun kenyataan di lapangan porsi melaksanakan tugas tertentu berbeda antara pamong belajar P2PNFI dan BPPNFI, BPKB, serta SKB. Sebagai contoh tugas melaksanakan pengembangan model penyelenggaraan pendidikan nonformal dan informal, untuk ini Pamong belajar di P2PNFI dan BPPNFI memiliki porsi yang besar, sementara Pamong belajar di SKB tidak melakukannya sama sekali.

Rerata kompetensi pedagogik pamong belajar di P2PNFI, BPPNFI, dan BPKB termasuk kategori sedang dan untuk pamong SKB termasuk kategori tinggi. Pada Gambar 5 tampak bahwa kelompok nilai tinggi, frekuensi tertinggi $(87,3$ persen) dicapai oleh Pamong belajar di SKB dan frekuensi terendah (48,39 persen) oleh Pamong
Belajar P2PNFI dan BPPNFI. Kondisi demikian adalah wajar, mengingat pamong belajar SKB lebih banyak melakukan pembelajaran di kelompok belajar dibandingkan dengan Pamong belajar P2PNFI, BPPNFI, dan BPKB. Pembelajaran dilakukan Pamong belajar SKB dalam kerangka sebagai penyelenggara di kelompok belajar. Sebagai penyelenggara yang sering menghadapi permasalahan kesulitan mencari Tutor, juga menjadi hal yang biasa jika penyelenggara juga merangkap sebagai tutor. Dengan seringnya melakukan pembelajaran adalah dimungkinkan jika pamong belajar memiliki wawasan pengetahuan tentang pedagogik yang cukup luas.

Rerata nilai kompetensi sosial pamong belajar termasuk kategori tinggi. Pada Gambar 6 tampak bahwa untuk kelompok nilai tinggi, frekuensi tertinggi $(90,91$ persen) dicapai oleh Pamong Belajar BPKB dan frekuensi terendah $(78,55)$ persen dicapai oleh Pamong Belajar P2PNFI dan BPPNFI. Secara umum dapat dikatakan bahwa kompetensi sosial Pamong Belajar P2PNFI, BPKB, dan SKB tergolong baik. 


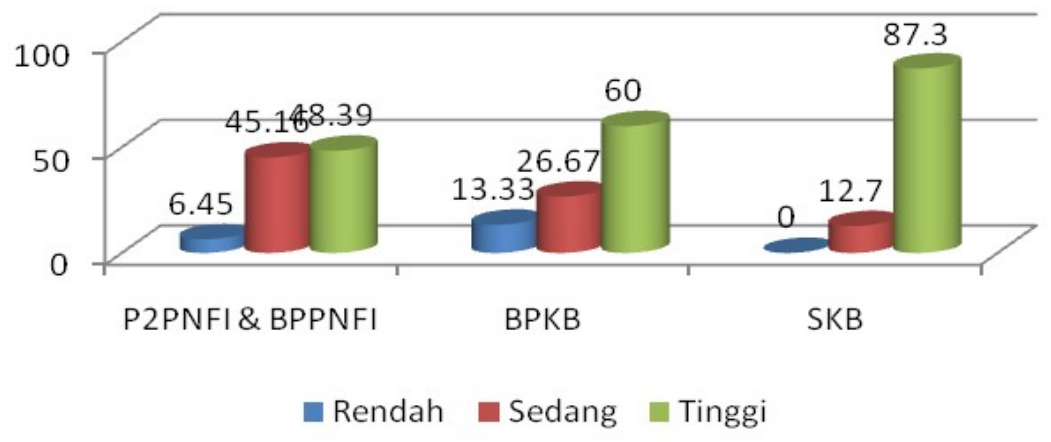

Gambar 5. Persentase Frekuensi Nilai Kompetensi Pedagogik Pamong Belajar

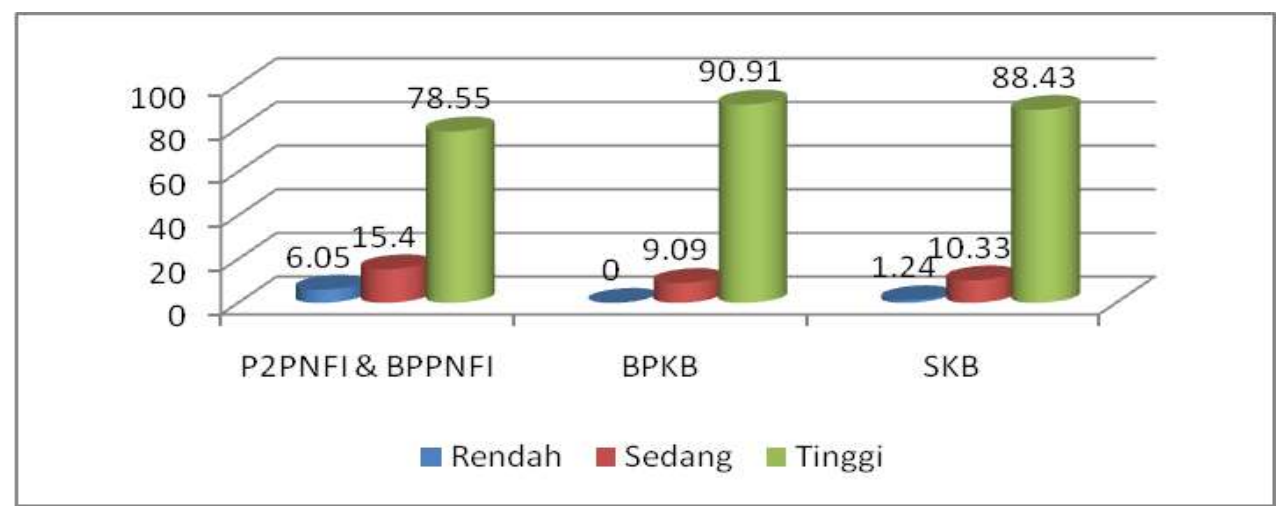

Gambar 6. Persentase Frekuensi Nilai Kompetensi Sosial Pamong Belajar

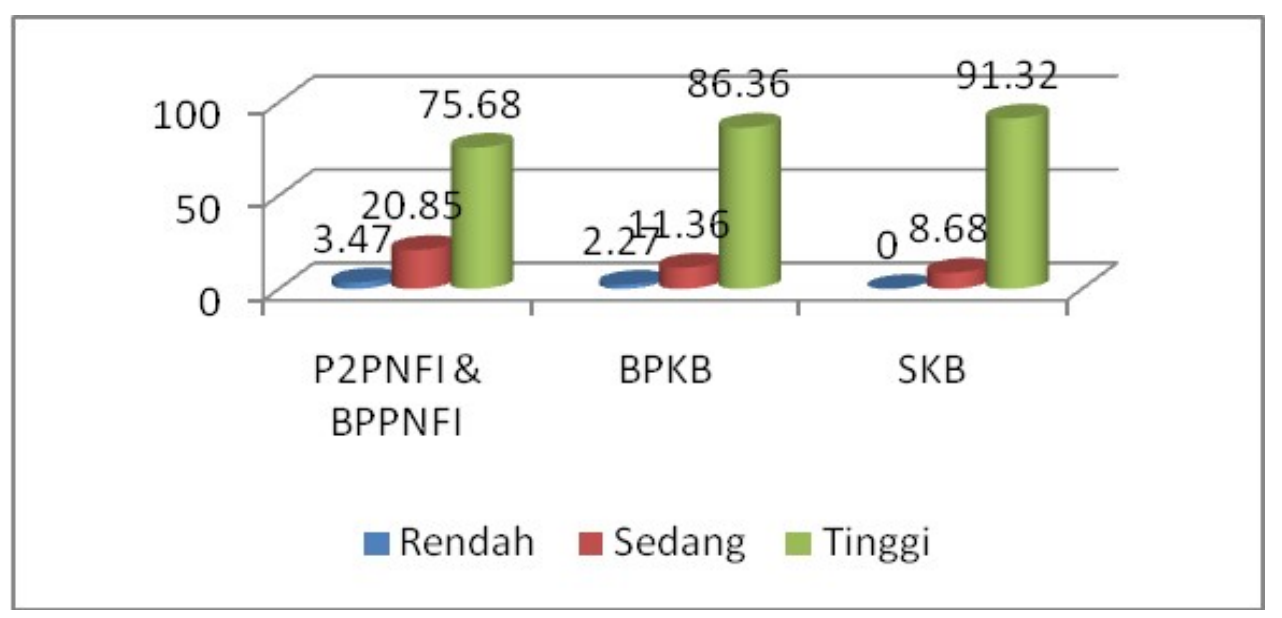

Gambar 7. Persentase Frekuensi Nilai Kompetensi Kepribadian

Rerata nilai kompetensi kepribadian pamong belajar tergolong tinggi. Tampak pada Gambar 7 bahwa kompetensi kepribadian Pamong Belajar P2PNFI, BPPNFI, BPKB, dan SKB secara umum baik ditunjukkan oleh tingginya persentase Pamong Belajar yang memperoleh nilai tinggi.

Berdasarkan hasil tes tersebut maka kompetensi pedagogik pamong belajar P2PNFI, BPPNFI, dan BPKB yang belum mencapai nilai tinggi perlu ditingkatkan minimal sampai pada tingkat kompetensi yang sesuai dengan tugas pokok dan fungsi masing-masing pamong belajar.

\section{Pengelola Kelompok Belajar}

Tenaga kependidikan yang dites kompetensinya hanya pengelola kelompok belajar Paket $A$ dan 
Paket B. Kompetensi yang dites adalah kompetensi kepribadian, sosial, dan manajerial. Rerata nilai kompetensi manajerial pengelola 30,13 dari 100. Dengan demikian, dapat dikatakan bahwa kemampuan pengelola masih sangat rendah. Rendahnya kemampuan pengelola dapat disebabkan karena mereka menjadi pengelola bukan karena kompetensinya tetapi karena memiliki akses untuk menjadi pengelola. Dengan demikian hal yang wajar jika kompetensi pengelola tampak seadanya saja. Kompetensi kepribadian dan sosial pengelola termasuk kategori tinggi.

Pada Gambar 8 tampak bahwa persentase tertinggi yaitu 66,98 persen adalah untuk kelompok nilai 21 sampai dengan 39, persentase terendah sebesar 16,04 persen adalah untuk kelompok nilai 40 sampai dengan 60. Dengan demikian, dapat dikatakan bahwa secara umum kemampuan pengelola kelompok belajar masih rendah. Hal ini kemungkinan disebabkan oleh 78,6 persen pengelola kejar baru memiliki pengalaman mengelola paling lama 5 tahun, sementara yang telah mengelola kejar selama 11 sampai dengan 15 tahun hanya 3,6 persen.

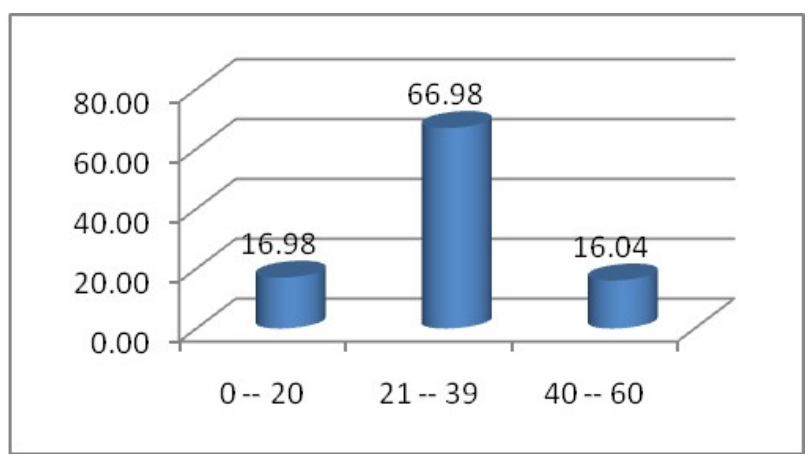

Gambar 8. Persentase Frekuensi Kelompok Nilai Kompetensi Manajerial Pengelola Kelompok Belajar

Rerata nilai kompetensi kepribadian pengelola kelompok belajar adalah tinggi yaitu 87,40. Gambar 9 memperlihatkan frekuensi tertinggi untuk kelompok nilai yang e" 76 . Dengan demikian dapat dikatakan kompetensi kepribadian pengelola tergolong baik.

Rerata nilai kompetensi sosial pengelola kelompok belajar adalah tinggi yaitu 79,55. Gambar 10 memperlihatkan frekuensi tertinggi untuk kelompok nilai yang e" 76 . Dengan demikian

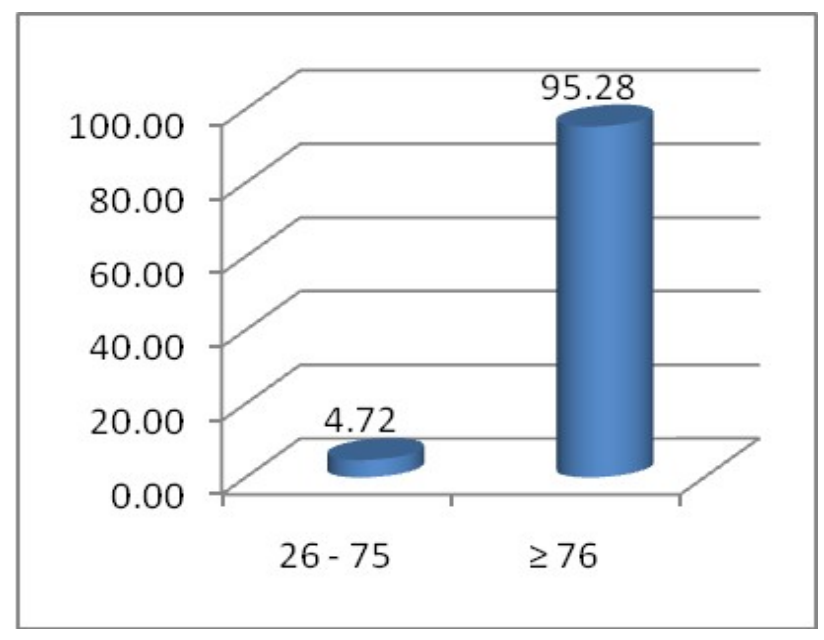

Gambar 9. Persentase Frekuensi Kelompok Nilai Kompetensi Kepribadian Pengelola Kelompok Belajar

dapat dikatakan kompetensi sosial pengelola adalah baik.

Berdasarkan hasil tes tersebut perlu diupayakan untuk meningkatkan kompetensi manajerial pengelola kelompok belajar Paket A dan Paket B dengan berbagai cara, di antaranya pelatihan, belajar dari sesama pengelola kelompok belajar lain yang berhasil.

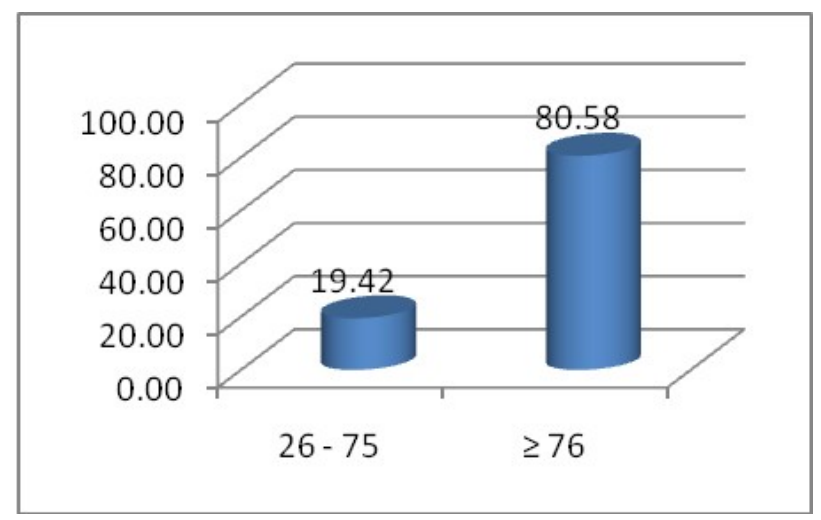

Gambar 10. Persentase Frekuensi Kelompok Nilai Kompetensi Sosial Pengelola Kelompok Belajar

\section{Faktor-faktor yang erat kaitannya dengan tingkat kompetensi PTKPNF saat ini}

Gambaran tentang dukungan dan hambatan PTKPNF di beberapa lembaga dalam meningkatkan kompetensinya.

\section{Dukungan Sarana dan Prasarana}

Pamong di P2PNFI, BPPNFI dan BPKB pada umumnya telah memiliki sarana prasarana 
memadai, hanya perlu ditambahkan buku-buku di perpustakaan. Bagi pamong di BPPNFI dan BPKB perlu disediakan laboratorium kelompok belajar yang dilengkapi dengan berbagai fasilitas pendukung yang memadai. Sama halnya dengan pamong di SKB, secara umum sarana prasarana memadai termasuk adanya fasilitas laboratorium kelompok belajar, namun buku-buku di perpustakaan masih perlu ditambahkan. Sedangkan untuk tutor paket $A$ dan paket $B$, keadaan sarana prasarananya bervariasi di masing-masing daerah, namun secara umum kondisi sarana prasarana di kelompok belajar masih memerlukan perhatian untuk meningkatkan mutu pendidikan.

Pengelola sebagai tenaga kependidikan memiliki sarana prasarana yang tidak jauh berbeda dengan tutor paket A dan paket B. Tenaga kependidikan lainnya adalah penilik. Sarana dan prasarana yang masih kurang bagi penilik adalah alat transportasi untuk menjalankan tugas.

\section{Dukungan Dana}

Pamong di P2PNFI mendapatkan block grant revitalisasi program dari Pemerintah Pusat. Pamong di P2PNFI dan BPPNFI berkesempatan mendapat dana beasiswa jenjang S2 dan S3 dari Pemerintah Pusat. Di BPKB, dana disediakan oleh Pemerintah Pusat untuk pelatihan sesuai dengan kebutuhan. Pemerintah daerah memberikan dana untuk memperbaiki bangunan dan pengadaan. Selain itu, pemerintah daerah juga memberikan dana untuk mengadakan pelatihan bagi pamong dan tutor, namun proses birokrasi memerlukan waktu yang lama.

Pamong di SKB mendapatkan dana dari BPKB Rp 1.500.000 per tahun untuk karya tulis dan pengembangan profesi. Lain halnya dengan tutor, rata-rata honor bulanan tutor paket $A$ sebesar Rp. 350.000,- sedangkan tutor paket $B$ berkisar Rp 350.000 sampai dengan Rp 400.000,- dari dana APBN. Untuk pengelola mendapat insentif Rp 300.000 per bulan.

\section{Dukungan Kebijakan}

Kebijakan tentang PB adalah Permenpan dan RB Nomor 15 Tahun 2010 tentang Jabatan Fungsional PB dan angka kreditnya. Peraturan ini memperbarui Keputusan Menkowasbangpan Nomor 25/
KEP/MK. WASPAN/6/1999. Dalam Permenpan dan RB Nomor 15 Tahun 2010 tentang Jabatan Fungsional Pamong Belajar dan Angka Kreditnya Pasal 7 ayat 6 menyatakan bahwa setiap kenaikan jenjang jabatan Pamong Belajar harus lulus uji kompetensi.

Dalam Permenpan Nomor 15 tahun 2010 juga ditetapkan bahwa kualifikasi akademik pamong menjadi DIV/S1. Pada peraturan sebelumnya kualifikasi akademik pamong adalah DII. Kebijakan tersebut memicu pamong untuk melanjutkan ke jenjang yang lebih tinggi. Menurut pamong dan tutor, kebijakan yang menunjang peningkatan kompetensi antara lain adalah pelatihan. Pamong mengharapkan, jika guru diberikan sertifikasi, maka pamong juga diberikan sertifikasi karena fungsi keduanya sama.

Kebijakan yang mendukung jabatan fungsional penilik antara lain adalah Peraturan Presiden Nomor 63 tahun 2010 tentang Batas Usia Pensiun yang dikeluarkan pada tanggal 25 Oktober 2010. Peraturan Presiden tersebut mengamanatkan penilik yang saat ini masih menjabat, batas usia pensiunnya dapat diperpanjang sampai dengan 60 tahun. Peraturan baru tersebut belum terlaksana di lapangan sehingga sebagian besar penilik belum memahaminya.

\section{Simpulan dan Saran Simpulan}

Berdasarkan hasil analisis disimpulkan beberapa hal sebagai berikut.

Pertama, kompetensi Tutor Paket A dan Paket B. Nilai kompetensi terendah yang dicapai oleh Tutor Paket A dan Tutor Paket B yaitu kompetensi pedagogik. Untuk kelompok tutor yang sama, kompetensi sosial tergolong sedang dan kompetensi kepribadian tergolong tinggi. Kompetensi professional Tutor Paket A dan Tutor Paket $B$ masih rendah, rerata nilai yang dicapai sebesar 40 dan 50,7 dari 100. Hal itu mencerminkan bahwa program kesetaraan dilakukan seadanya, yang penting adalah program yang direncanakan dapat dilaksanakan meskipun dengan berbagai keterbatasan, termasuk keterbatasan kompetensi penguasaan substansi. Kedua, kompetensi Pamong Belajar. Pada umumnya nilai pengetahuan kompetensi sosial, 
kepribadian dan professional pamong belajar tinggi. Variasi nilai pengetahuan kompetensi lebih banyak pada kompetensi pedagogik. Nilai rerata pengetahuan kompetensi pedagogik pamong belajar di P2PNFI, BPPNFI, dan BPKB termasuk kategori sedang dan untuk pamong SKB adalah tinggi. Ketiga, kompetensi Pengelola Kelompok Belajar Paket A dan Paket B. Rerata nilai kompetensi manajerial pengelola tergolong rendah yakni 30,13 dari 100. Rerata nilai kompetensi sosial dan kepribadian pengelola kelompok belajar adalah tinggi yaitu berturut-turut 79,55 dan 87,40. Keempat, sarana pendidik. Pamong belajar di P2PNFI, BPPNFI, BPKB dan SKB pada umumnya telah memiliki sarana prasarana memadai seperti komputer dan jaringan internet. Sarana dan prasarana yang belum mencukupi adalah buku-buku di perpustakaan dan laboratorium kelompok belajar. Untuk tutor paket A dan paket B, keadaan sarana prasarananya bervariasi di masing-masing daerah, namun secara umum kondisi sarana prasarana di kelompok belajar masih memerlukan perhatian untuk meningkatkan mutu pendidikan. Kelima, sarana Tenaga Kependidikan. masih belum memadai, sedangkan untuk sarana transportasi menjalankan tugas, sebagian penilik masih belum memiliki. PTK PNF masih belum banyak mengetahui tentang kebijakan Keenam, Pemerintah untuk meningkatkan kompetensi, kemungkinan disebabkan kurangnya sosialisasi di tingkat pelaksana, terutama di daerah-daerah yang aksesnya sulit dijangkau. Dengan kondisi tersebut mengakibatkan tidak terlaksananya berbagai kebijakan Pemerintah tentang peningkatan kompetensi PTK PNF.

\section{Saran}

Berdasarkan simpulan tersebut, disarankan beberapa hal sebagai berikut.
Pertema, Kompetensi profesional dan pedagogik tutor paket $A$ dan paket $B$ perlu ditingkatkan dengan menyelenggarakan pelatihan tutor, kursus berjenjang, pemberdayaan tutor inti, dan magang. Khusus untuk tutor paket $B$, peningkatan kompetensi profesional perlu disesuaikan mata pelajaran yang diajarkan. Selanjutnya, peningkatan kompetensi profesional dan pedagogik tutor paket $A$, lebih ditekankan pada peningkatan jenjang pendidikan mereka, khususnya bagi mereka yang berijazah SMA. Hal ini mengingat jumlah tutor paket $A$ yang berijazah SMA cukup banyak, yaitu 28 persen. Kedua, Pengajuan proposal program Paket A sebaiknya mensyaratkan memiliki tutor yang berlatar belakang pendidikan keguruan. Adapun untuk program paket $B$, pengajuan proposal tidak hanya mensyaratkan tutor yang memiliki pendidikan keguruan, melainkan juga tutor yang memiliki kesesuaian antara mata pelajaran yang diajarkan dengan jurusan pendidikannya. Ketiga, perlunya dukungan dari Pemerintah dan Pemerintah Daerah untuk meningkatkan ketersediaan sarana dan prasarana operasional para tutor, pamong belajar, pengelola, dan penilik. Khusus untuk penilik perlu diberikan fasilitas transportasi. Untuk memotivasi kinerja, sebaiknya insentif untuk tutor dan pengelola ditingkatkan. Keempat, P2PNFI, BPPNFI, BPKB dan SKB perlu dimotivasi untuk mengadakan dan mengembangkan laboratorium kelompok belajar untuk melaksanakan tugas mengajar. Hal ini sejalan dengan Peraturan Menteri PAN dan Reformasi Birokrasi Nomor 15 tentang Jabatan Fungsional dan Angka Kreditnya yang menuntut pamong belajar melaksanakan tugas mengajar untuk mendapatkan angka kredit. Sebaiknya setiap kabupaten/kota memiliki SKB untuk menggerakkan program-program PNFI. Perlunya sosialisasi kebijakan pemerintah tentang peningkatan kompetensi PTKPNF, termasuk ke daerah yang aksesnya sulit dijangkau.

\section{Pustaka Acuan}

Departemen Pendidikan Nasional. 2006. Standar Kompetensi PTK-PNF dan Sistem Penilaian. Jakarta: Direktorat Pendidik dan Tenaga Kependidikan Pendidikan Nonformal, Direktorat Jenderal Peningkatan Mutu Pendidik dan Tenaga Kependidikan.

Hargreaves, David H. 2001. A Capital Theory of School Effectiveness and Improvement. British Educational Research Journal, Volume 27(4). 
Keputusan Menkowasbangpan Nomor 25/KEP/MK.WASPAN/6/1999. Tentang Jabatan Fungsional Pamong Belajar dan angka kreditnya.

Olanivan, D.A. and Okemakinde, T. 2008. Human Capital Theory: Implications for Educational Development. European Journal of Scientific Research, Volume 4(2).

Peraturan Menteri Penerbitan Aparatur Negara dan Reformasi Birokrasi Nomor 15 Tahun 2010 tentang Jabatan Fungsional Pamong Belajar dan Angka Kreditnya.

Peraturan Pemerintah Nomor 19 tahun 2005 tentang Standar Nasional Pendidikan. Jakarta: Depdiknas

Peraturan Presiden Nomor 63 tahun 2010 tentang Batas Usia Pensiun. Undang-Undang Nomor 20 tahun 2003 tentang Sistem Pendidikan Nasional. Jakarta: Depdiknas. UNESCO. 2005. Education For All (EFA) Global Monitoring Report -The Quality Imperative. 